\title{
Competitiveness of Hungarian Urban Micro-regions: Localization Agglomeration Economies and Regional Competitiveness Function*
}

\section{Introduction}

Increasing regionalization represents one of the most spectacular processes of the economies that develop and transform as a result of globalization processes; while the (relative) importance of national economies is decreasing, the economic role of regions and cities seems to grow. Global competition has also intensified spatially, especially with the growing importance of the agglomeration economies. Interregional competition, which refers to the competition of regions and cities for scarce resources, educated human labour, investments etc., is increasingly prevalent (Enyedi 2009).

It appears to be generally accepted in regional science these days, that there is some sort of competition among regions, but this may be characterized by different attributes such as the competition among corporations or countries (Batey-Friedrich 2000, Chesire 2003, Malecki 2002). Capello states (2007a, xviii): 'Regions compete on absolute rather than comparative advantage". The results of interregional competition are similar to those of the competition among countries: welfare (living standard) improves in the successfully competing regions, employment and incomes (wages) are high, new investments take place, talented young people and successful businessmen migrate there, etc. (Malecki 2004, Polenske 2004). Successfulness in competition, or in other words, competitiveness has been one of the key concepts over the past two or three decades partly due to the sharpening of global competition (Camagni 2002).

Today territorial competitiveness covers both economic growth and economic development. This complex point of view is well demonstrated by the fact that Capello (2007a) emphasizes the connections between territorial competitiveness and local development, as well as regional growth (both for endogenous and exogenous) in her book entitled 'Regional economics'. However, while theoretical approaches of econometric regional growth between 1960 and 1990 were based on increasing productivity and individual welfare indicators as described by traditional neoclassical models, the shift in the 1990s resulted in a definite turn towards strengthening competitiveness (Capello 2007b). In territorial endogenous growth theories, regional growth is the result of partly independent mechanisms (Capello 2007b, pp. 757-758): a competitive process, a socio-relational process, a territorial and spatial process, an interactive process, and an endogenous process.

\footnotetext{
* This research was supported by the TÁMOP 4.2.1/B-09/KONV-2010-0005 project of the Hungarian National Development Agency.
} 
The modes of improving regional competitiveness and regional economic development strategies are heavily dependent on the type of the given region. This is because regions in different phases of their development are in different positions when it comes to interregional competition. Porter et al (2008) classified these phases as: resource-driven stage, investment-driven stage, and innovation-driven stage. These categories are especially important in understanding regional development in transition economies, where regions are hardly in the innovation-driven phase (Lengyel-Cadil 2009, Lengyel-Leydesdorff 2010, Lengyel 2009b). However, based on agglomeration advantages Budd-Hirmis (2004) points out that metropolitan regions with urbanization agglomeration economies are competing with more emphasis on their comparative advantages, while regions of localization agglomeration economies tend to compete on competitive advantages. McCann (2008) considers that size of regions is a strong influential factor when it comes to the organization of clusters, which play a very important role in interregional competition: pure agglomeration (urban), industrial complex (local but not urban), and social networks (local but not urban).

The next section of this paper covers the pyramidal model of regional competitiveness. This model is a logical systematization for measuring endogenous regional growth and the factors influencing it; the model will be used to introduce the regional competitiveness function (RCF). After introducing the theoretical model, we are going to investigate the competitiveness of Hungarian urban micro-regions (LAU1) with a population of above 50 thousand citizens. Our statistical analysis to underline the classification of micro-regions by competitiveness types is based on the multivariate linear regression analysis.

\section{Pyramidal model and regional competitiveness function (RCF)}

Three major issues emerged in the debates aiming at the interpretation of competitiveness (Barkley 2008): (1) how to define regional competitiveness and its factors; (2) what indicators should be used to measure it; and (3) how can regional competitiveness be improved? These three questions usually lie in the background of other professional debates too; while representatives of regional science concentrate on the first one, the regional economist on the second one, the experts of regional policy tend to focus on the third one.

There were a number of attempts to define the new notion of competitiveness according to new global competition conditions in the mid-1990s. The standard notion of competitiveness in the European Sixth Regional Periodic Report of EU (EC 1999): 'The ability of companies, industries, regions, nations and supra-national regions to generate, while being exposed to international competition, relatively high income and employment levels'. In the European Competitiveness Report (EC 2008, p. 15): “Competitiveness is understood to mean a sustained rise in the standards of living of a nation or region and as low a level of involuntary unemployment, as possible." In other words 'high and rising standards of living and high rates of employment on a sustainable basis' (EC 2001).

Porter (2007) suggests using prosperity, measured by standard of living and inequality for measuring regional competitiveness. Prosperity, defined by per capita income is decomposed into two factors: labour productivity and labour utilization. 
Factors influencing labour productivity are skills, capital stock, and total factor productivity. Factors of labour utilization are working hours, unemployment, and workforce participation rate (population age profile).

Kitson, Martin, and Tyler (2004) use three indicators for measuring competitiveness: regional productivity, employment, and standard of living. They also claim that competitiveness is influenced by hard and soft elements as well. The bases of the regional competitive advantage are: productive capital, human capital, social-institutional capital, cultural capital, infrastructural capital, and knowledge/creative capital. The region-specific economic and social qualities, like social capital, knowledge/creative capital, and territorial capital are gaining more and more in importance (Camagni 2009, Lengyel I. 2009a). Thus, regional competitiveness studies are increasingly influenced by theories of endogenous growth and development.

Stimson, Stough, and Salazar (2009) suggest a new conceptual model framework for regional endogenous development. The dependent variable of endogenous growth is measured by two indicators, on one hand by the change of employment or income, on the other hand by an employment-based location quotient (LQ). Explanatory variables include, among others, resource endowments (estimated by 13 indicators) and market fit (measured by 4 indicators). Their model includes several indicators for leadership quality, as well as institutions and entrepreneurship.

The standard notion of competitiveness obtained in this way cannot be used, however, to identify factors responsible for regional competitiveness or areas, which are to be strengthened or developed by regional development policies and programmes for improved competitiveness. Since the notion of competitiveness can be seen as refining that of economic growth, it can often be observed that proposals for improved competitiveness combine traditional means of economic development with methods based on endogenous development.

The standard definition refers to "relatively high income". This can be measured by means of the per capita GDP and the GDP growth rate. A high employment level is in turn indicated by the rate of employment. These two indicators can be measured independently from one another, but per capita GDP can also be expressed as follows, respectively:

$$
\frac{G D P}{\text { total.population }}=\frac{G D P}{\text { employment }} \times \frac{\text { employment }}{\text { working-age.pop. }} \times \frac{\text { working-age.pop. }}{\text { total.population }} .
$$

This formula suggests that measuring regional competitiveness can be traced back to two interdependent economic categories (Lengyel 2004):

Regional income $\cong$ Labour productivity $\times$ Employment rate.

Hence the substance of regional competitiveness: the economic growth in the region, which growth is generated by both a high level of labour productivity and a high level of employment. In other words, competitiveness means economic growth driven by high productivity and a high employment rate.

Our study reviewing the competitiveness of Hungarian micro-regions is built on the pyramidal model since it is coherent with the above-mentioned findings, and is established on the basis on the inputs- outputs- outcomes relationship (Figure 1). The target (outcomes) is the standard of living; the prosperity of any region depends on its 
competitiveness. Outputs are the revealed competitiveness indicators: per capita Gross Regional Product, labour productivity, and employment rate. Sources of competitiveness, inputs influencing regional competitiveness can be divided into two groups of direct and indirect components. Of particular importance are competitiveness factors with a direct and short-term influence on economic output, labour productivity, and employment rates. Nevertheless, social, economic, environmental and cultural processes and parameters, the 'success determinants', with an indirect, long-term impact on competitiveness are also to be taken into account.

Figure 1

The renewed pyramidal model of regional competitiveness

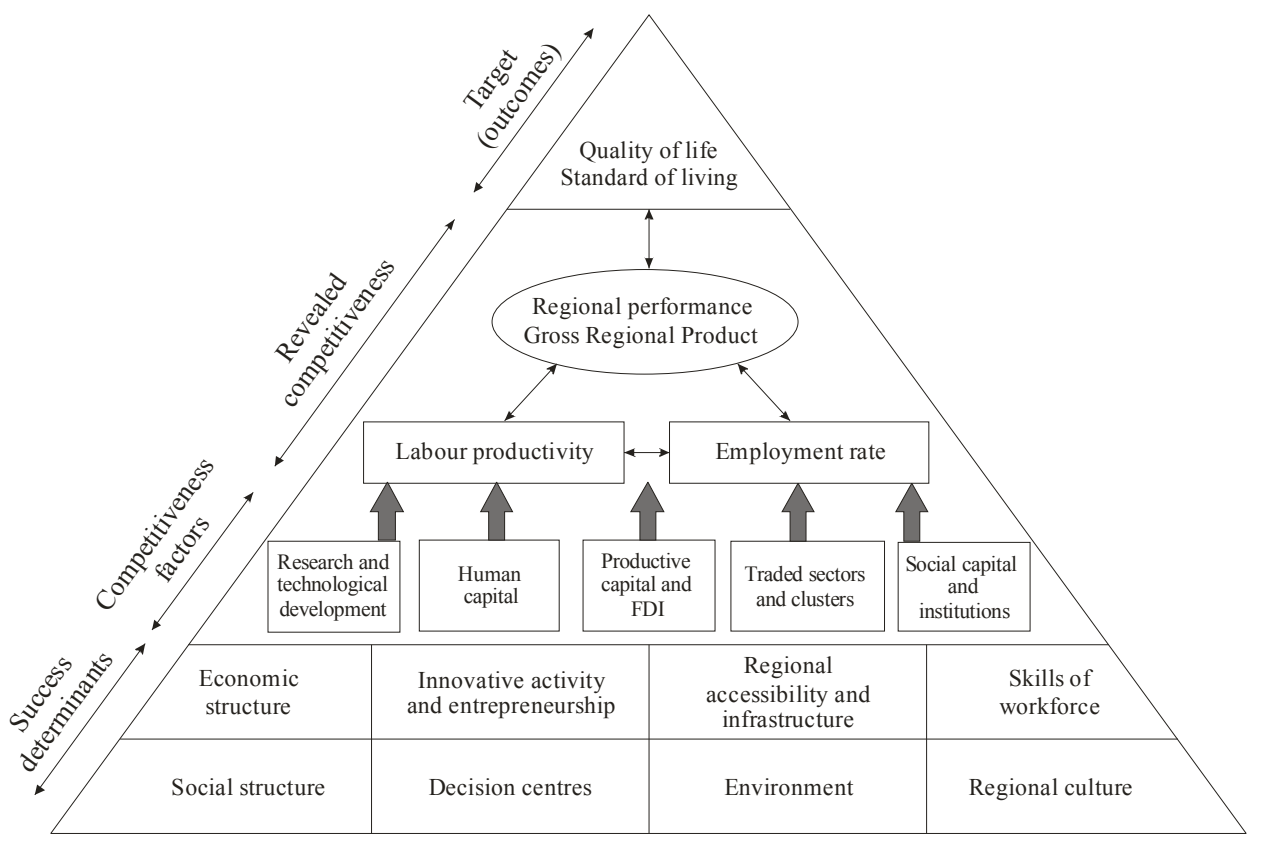

Source: Based on Lengyel, I. (2000, 2004).

Three levels can be distinguished with regard to the objectives of regional development programming and the various characteristics and factors influencing competitiveness:

- Revealed competitiveness (or basic categories) (ex post indicators, output): these categories measure competitiveness and include income, labour productivity and employment rate.

- Competitiveness factors (ex-ante factors): input factors with an immediate impact on revealed competitiveness categories. These can be used to influence regional competitiveness by means of institutions in short-term programming periods.

- Success determinants (social, economic, and environmental backgrounds): input determinants with an indirect impact on basic categories and competitiveness factors. These determinants take shape over a longer period and their significance reaches beyond regional policy-making. 
The pyramidal model of regional competitiveness seeks to provide a systematic account of these means and to describe the basic aspects of territorial competitiveness. 'This model is useful to inform the development of the determinants of economic viability and self-containment for geographical economies' (Pike et al. 2006, p. 26). 'This is an aggregate notion, in a regional context, labour productivity is the outcome of a variety of determinants (including the sort of regional assets alluded to previously). Many of these regional factors and assets also determine a region's overall employment rate. Together, labour productivity and employment rate are measures of what might be called 'revealed competitiveness', and both are central components of a region's economic performance and its prosperity (as measured, say, by GDP per capita), though obviously of themselves they say little about the underlying regional attributes (sources of competitiveness) on which they depend' (Gardiner-Martin-Tyler 2004, p. 1049).

Competitiveness factors of the renewed pyramidal model include such constituents of endogenous development theory like social capital and regional specialization, besides traditional factors of production like capital, labour, and technology:

- RTD - Research and technological development (RTD): rapid introduction of innovations and new technologies creates competitive advantages. Innovation may come from outside the region (e.g. technological transfer), but the competitiveness of the region is most effectively advanced by successful R\&D activities, innovations and their fast and wide-ranging distribution. The introduction of innovations and creation of patents may be effectively advanced by knowledgeintensive businesses.

- HUM_CAP - Human capital: population of active age, size and age structure of the workforce are important growth factors. However, the education level of the workforce is also important, especially the rate of people holding a tertiary degree.

- CAP_FDI - Productive capital and FDI: capital is indispensable for improving the competitiveness of a region. Investments from outside the region, especially foreign direct investments, usually create new sectors, markets, new technologies, and new jobs. It also improves labour productivity and can also encourage technological transfer.

- TS_CLUST - Traded sectors, entrepreneurship, and clusters: a strong traded (export-oriented) sector is an important source of competitiveness, which may become even more competitive by clustering. Flexible regional specialization may be furthered by entrepreneurship and small and medium-sized enterprises (SMEs). Innovative SMEs are flexible and can quickly adapt to market changes, they are principally responsible for generating employment in the region.

- SOC_CAP - Social capital and institutions: economic prosperity also presupposes efficient cooperation among firms, governmental and non-governmental institutions. Successful companies also depend on the level of administrative services and public institutions. Social capital is particularly important: trust, reliability, readiness to cooperate, etc.

In order to investigate the relations between indicators of revealed competitiveness (RC) and competitiveness factors, we intend to introduce the Regional Competitiveness Function (RCF):

$$
\mathrm{RC}=\mathrm{f}\left(\mathrm{RTD}, \mathrm{HUM} \_\mathrm{CAP}, \mathrm{CAP} \text { _FDI, TS_CLUST, SOC_CAP }\right) \text {. }
$$


The basic premise of the study is thatwe assume that there is a relationship between competitiveness factors and revealed competitiveness. Causality is to be determined by multivariate regression. Our dependent variable is revealed competitiveness measured by a calculated index, while the five competitiveness factors are explanatory variables.

RCF is an extension of traditional regional growth concepts from the latest work on endogenous growth research. The importance of traded sectors and regional specialization is pointed out by Porter $(2003,2008)$, Stimson, Robson, and Shyy (2009), while Acs and Szerb (2007), Fischer and Nijkamp (2009) emphasize the significance of SMEs and entrepreneurship, and Varga $(2006,2007)$ stresses the importance of innovation and knowledge spillover. Sociological research alludes to the importance of social capital (and territorial capital), brought to the attention of regionalists by Camagni (2009), Faggian and McCann (2009), Florida (2002) and Glaeser (2008).

The weight of each RCF competitiveness factor in measuring revealed competitiveness was assessed during our study of Hungarian micro-regions. This assessment excluded the success determinants of the pyramidal model, because we assume that the RCF is mainly useful for describing short-term relationships.

\section{Background of competitiveness studies in Hungary}

Regional competitiveness studies tend to be relative, i.e. we mostly compare the competitiveness of the chosen regions to each other. It is recommended to choose nodal regions, because workforce commuting, business relationships, etc. rarely adhere to the spatial distribution of normative regions. It is difficult to gather reliable statistical data about nodal (functional) regions, thus Level LAU1 micro-regions were chosen this time. We assume that, except for Budapest, micro-regions are able to provide a good assumption of workforce commute zones (Lukovics 2009, Szakálné Kanó 2011).

In 2008, Hungary consisted of 7 regions (NUTS 2), 19 counties (NUTS 3) and the capital, as well as 174 micro-regions (LAU 1). Statistical data usable for competitiveness investigations are available for these territorial levels. All LAU1 micro-regions have a town centre.

The indicators of revealed competitiveness (GDP per capita, employment, labour productivity) show a broad distribution in LAU1 micro-regions. Examining employment rates by micro-regions based on their populations, one may get a very diversified distribution (Figure 2). Employment rates in micro-regions with less than 70 thousand inhabitants (four fifth of micro-regions) are distributed evenly, mostly between $35 \%$ and $60 \%$. In those 31 micro-regions with more than 50 thousand inhabitants in their town centres (so-called urban micro-regions), employment rates vary between 45 and 55\% (in Budapest it is $56.6 \%$ ). It can be established that the critical mass, population as employees and consumers, as well as more sophisticated business and other urban services are crucially important factors in the development of employment (BajmócySzakálné Kanó 2009). 
Employment rate and population of LAU1 micro-regions

Figure 2

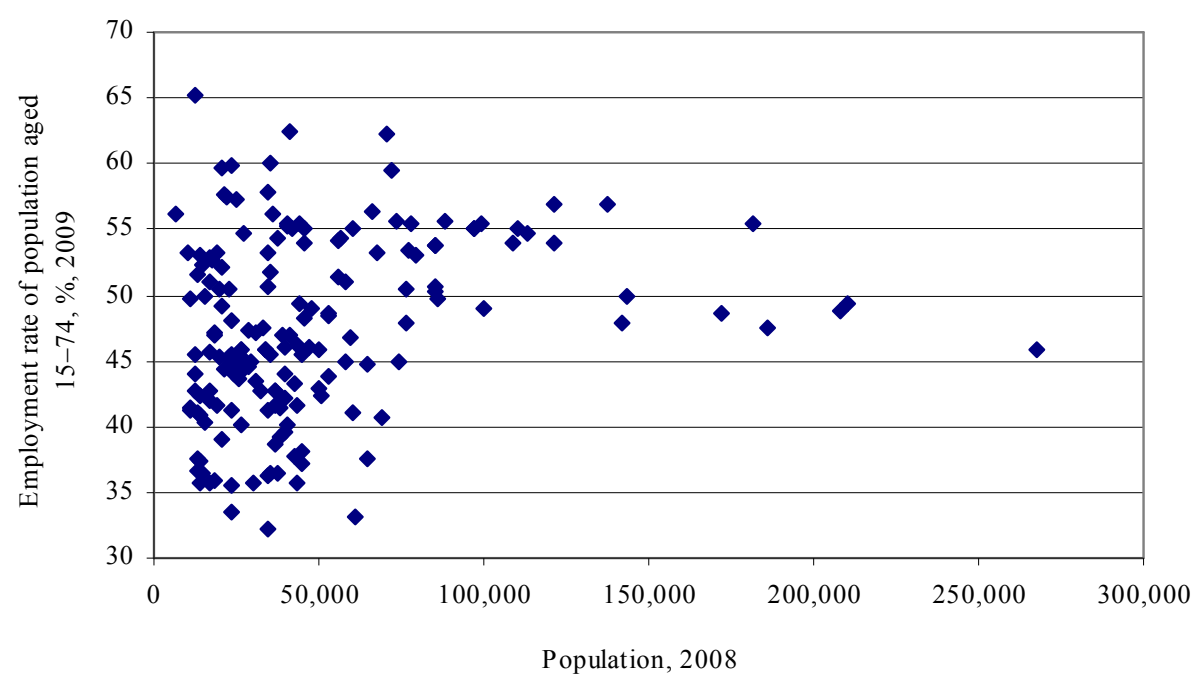

Source: Calculations of authors based on National Employment Office (http://kisterseg.afsz.hu/index.php) and KSH Territorial Statistical Yearbook.

Note: Without Budapest.

\section{Unemployment rate and population of micro-regions}

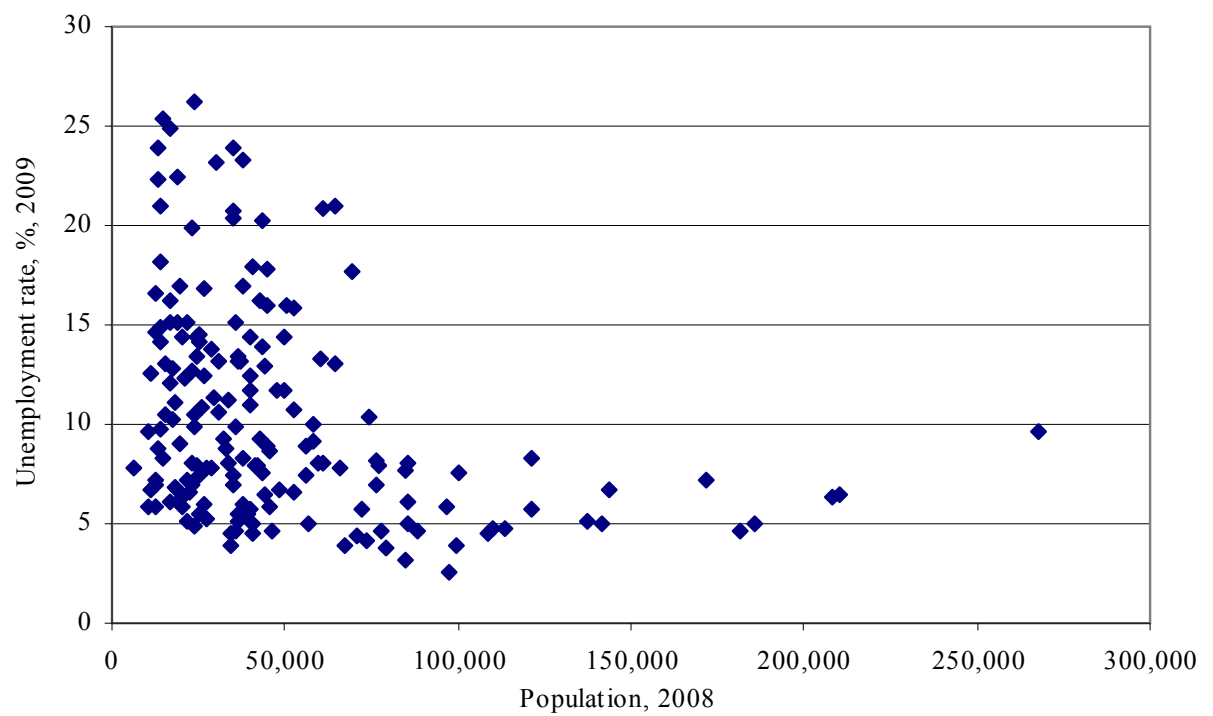

Source: Calculations of authors based on National Employment Office (http://kisterseg.afsz.hu/index.php) and KSH Territorial Statistical Yearbook.

Note: Without Budapest. 
Unemployment rates have an opposite relationship (Figure 3). With this indicator, an important milestone can also be seen at 50 thousand urban inhabitants: more populated micro-regions have unemployment rates of 5 to $10 \%$, while less populated micro-regions have between 7 and $28 \%$. No influence on this situation can be seen in micro-regions with less than 50 thousand urban inhabitants, as these have a similar distribution as larger ones.

Our empirical study includes urban micro-regions, with more than 70 thousand inhabitants (and more than 50 thousand urban inhabitants), potentially able to show localization agglomeration advantages. The groups of 174 micro-regions, according to agglomeration economies:

- Budapest (population of 2 million): urbanization agglomeration economies (Jacobs' externalities),

- 31 micro-regions with urban centre, as urban micro-regions (at least 50,000 population of urban centres, sum total 3.6 million population): localization agglomeration economies (Marshall' externalities),

- 142 small (rural type) micro-regions (sum total 4.4 million population).

Budapest was intentionally left out of this study due to its vastly different characteristics. To sum up, urban micro-regions with potential localization agglomeration economies were studied by using the pyramidal model.

\section{Empirical testing of the Regional Competitiveness Function}

Our empirical study included the competitiveness of 31 urban micro-regions. Goals of the investigation:

- comparison of these micro-regions by competitiveness, ranking, establishment of region types,

- to show how the indicators and indicator groups used influence regional competitiveness.

Our study adheres to the logical construction of the pyramidal model. Revealed competitiveness indicators show recently achieved competitiveness as ex-post indicators. Competitiveness factors point out their contribution to revealed competitiveness. On the other hand, these show 'capabilities' and future possibilities as ex ante indicators: by developing these, we can see how the competitiveness of micro-regions might change in the near future.

Difficulties were liable to occur during the database creation process, because several theoretical categories (like social capital) are not straightforward to operationalize, and it is difficult to obtain reliable and authentic data for all Hungarian micro-regions (Bajmócy-Lukovics-Vas 2010). Computer analysis was done with SPSS-18. ${ }^{1}$

The basic idea of our study: we assume that there is a relationship between competitiveness factors and revealed competitiveness. Causality is to be determined by multivariate regression. Our dependent variable is revealed competitiveness measured by a calculated index, while the 5 competitiveness factors are explanatory variables.

1 Micro-regional competitiveness indicators and database were collected by Miklós Lukovics, Zoltán Bajmócy and György Málovics, thanks for their help. 
Our multivariate linear regression model:

$R C=\beta_{0}+\beta_{1} R T D+\beta_{2} H U M_{-} C A P+\beta_{3} C A P \_F D I+\beta_{4} R S \_C L U S T+\beta_{5} S O C \_C A P+\varepsilon$.

The indicators used were set up based on the pyramidal model (see Appendix 1):

- revealed competitiveness (RC) is calculated by 3 indicators,

- competitiveness factors are described by a total of 34 indicators: RTD (5 indicators), HUM_CAP (9 indicators), CAP_FDI (6 indicators), RS_CLUST (6 indicators), SOC_CAP (8 indicators).

To test RCF, we first calculated the value of revealed competitiveness; afterwards we analysed it with multivariate linear regression to determine how far competitiveness factors are able to explain the value of revealed competitiveness.

\section{(a) Revealed competitiveness}

Micro-regions may show enormous distortion due to data localization, therefore it might be misleading to calculate GDP, also major companies are calculated as being a onepoint business at their headquarters' location. Therefore we concluded that 3 out of the revealed competitiveness (PIT_INH: taxable income per capita; GVA_EMPL: gross value added per employee; EMPL_RATE: employment rate) shall undergo principal component analysis to determine the principal component (RC), which shall be used later on as the dependent variable:

- RC contains $60.7 \%$ of the 3 indicators,

- commonalities: PIT_INH 0,835; GVA_EMPL 0,5; EMPL_RATE 0,485.

Based on principal component analysis we found four types of Hungarian urban micro-regions (Figure 4):

- the most competitive 6 micro-regions are found in Transdanubia (Dunaújváros, Győr, Székesfehérvár) with significant foreign-owned manufacturing capacities, as well as in the western agglomeration of Budapest,

- the second type ( 8 micro-regions) includes all other Northern Transdanubian micro-regions with some further micro-regions to the east of Budapest,

- the third type (11 micro-regions) includes other county capitals, with poor economy and human capital, as well as in the southern agglomeration of Budapest,

- while the least competitive 6 regions are found in the southern and eastern part of the country with some rural settlements. 


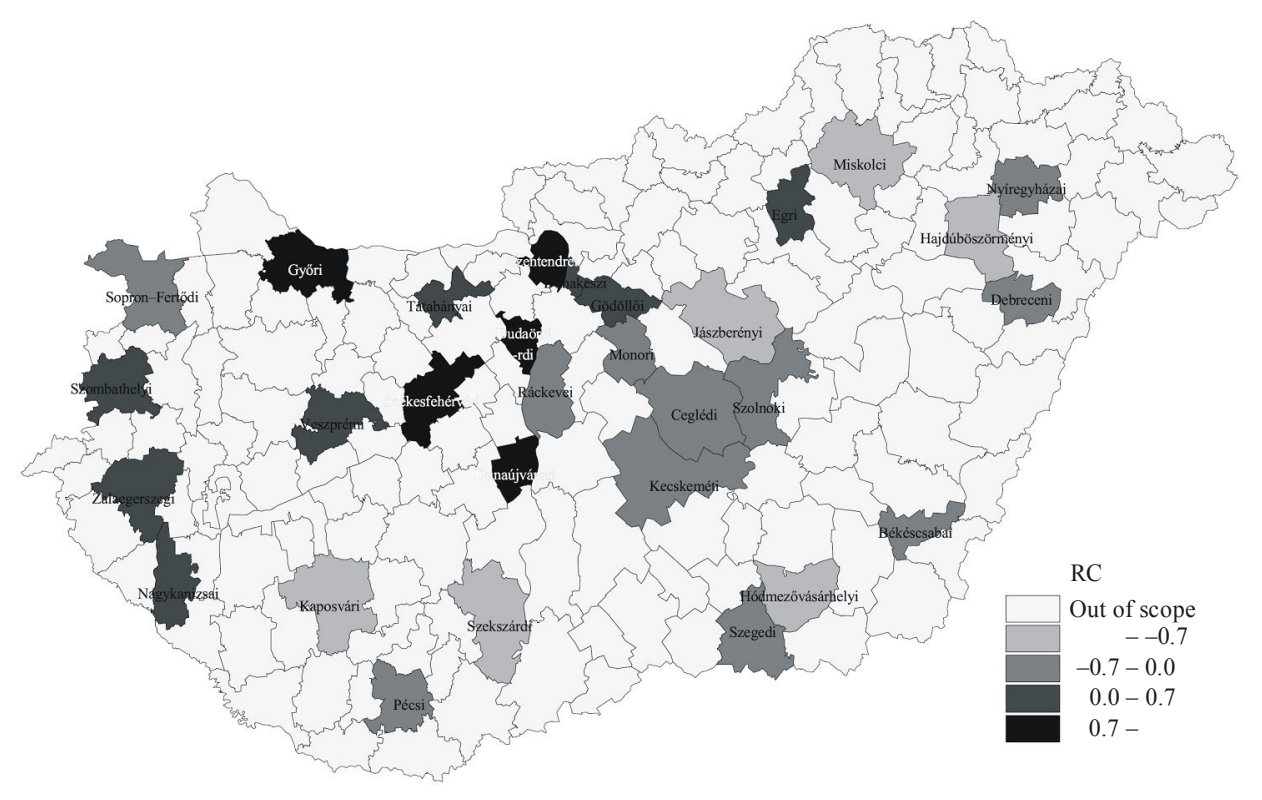

(b) Relationship between competitiveness factors and $R C$

The analysis included the effect of the 5 competitiveness factors of the renewed pyramidal model on the dependent variable (RC). Each competitiveness factor was based on 5 to 9 indicators, therefore we performed factor analysis within the indicator group in order to compress information and establish 1 to 2 factors per indicator group:

- RTD (research and technological development): one single factor, including $68 \%$ of information,

- HUM_CAP (human capital): two factors, one containing 36.8\% (HUM_CAP1), the other 33.6\% (HUM_CAP2) of the information,

- CAP FDI (productive capital and FDI): one single factor, including $68 \%$ of the information,

- TS CLUST (regional specialization and clusters): two factors, one explaining $39.3 \%$ (TS_CLUST1), the other $36.1 \%$ (TS_CLUST2) of the information,

- SOC_CAP (social capital and institutions): two factors, one explaining 31.6\% (SOC_CAP1), the other $30.0 \%$ (SOC_CAP2) of the information available.

The above-mentioned 8 factors were used in multivariate linear regression, where $\mathrm{RC}$ was considered a dependent variable and the forward method resulted in 2 factors: CAP_FDI and SOC_CAP2. These two factors account for $85.2 \%\left(\mathrm{R}^{2}=0.852\right)$ of the dependent variable's $(\mathrm{RC})$ standard deviation.

The model created:

$$
R C_{i}=+0,452 C A P_{-} F D I_{i}-0,615 S O C_{-} C A P 2_{i}+e_{i} .
$$


The regression model provides adequate explanation for the dependent variable:

- there is no multicollinearity to observe, $\mathrm{VIF}=1.308$,

- residuals show a normal distribution,

- there is no heteroscedasticity to observe.

Indicators having major influence on the competitiveness of micro-regions

\begin{tabular}{l|c|l|c}
\hline \multicolumn{1}{c|}{ CAP_FDI } & Component & \multicolumn{1}{|c}{ SOC_CAP2 } & Component \\
\hline CONS-INH & 0.773 & PAYER-PIT & -0.653 \\
SHARE-INH & 0.936 & POOR & 0.858 \\
FDI-INH & 0.963 & CULT & 0.029 \\
FDI-CAP & 0.962 & DIS-PENS & 0.731 \\
FDI-EMPL & 0.944 & DIPL-LOCAL & -0.041 \\
FDI-REV & 0.950 & CRIME & 0.039 \\
& & UNEMPL-RATE & 0.835 \\
& & NONGOV & 0.075
\end{tabular}

Based on these results, these two factors explain the competitiveness of micro-regions (Table 1). The first factor (CAP_FDI) only includes positive variables: a foreign direct investment, total assets of enterprises (CONS-INH) and paid-in capital of enterprises in the micro-region (SHARE-INH). In the second factor (SOC_CAP2): the proportion of personal income taxpayers increases, while poverty rate, unemployment rate and disability pensioners reduce competitiveness.

Micro-regions by CAP_FDI factor

Figure 5

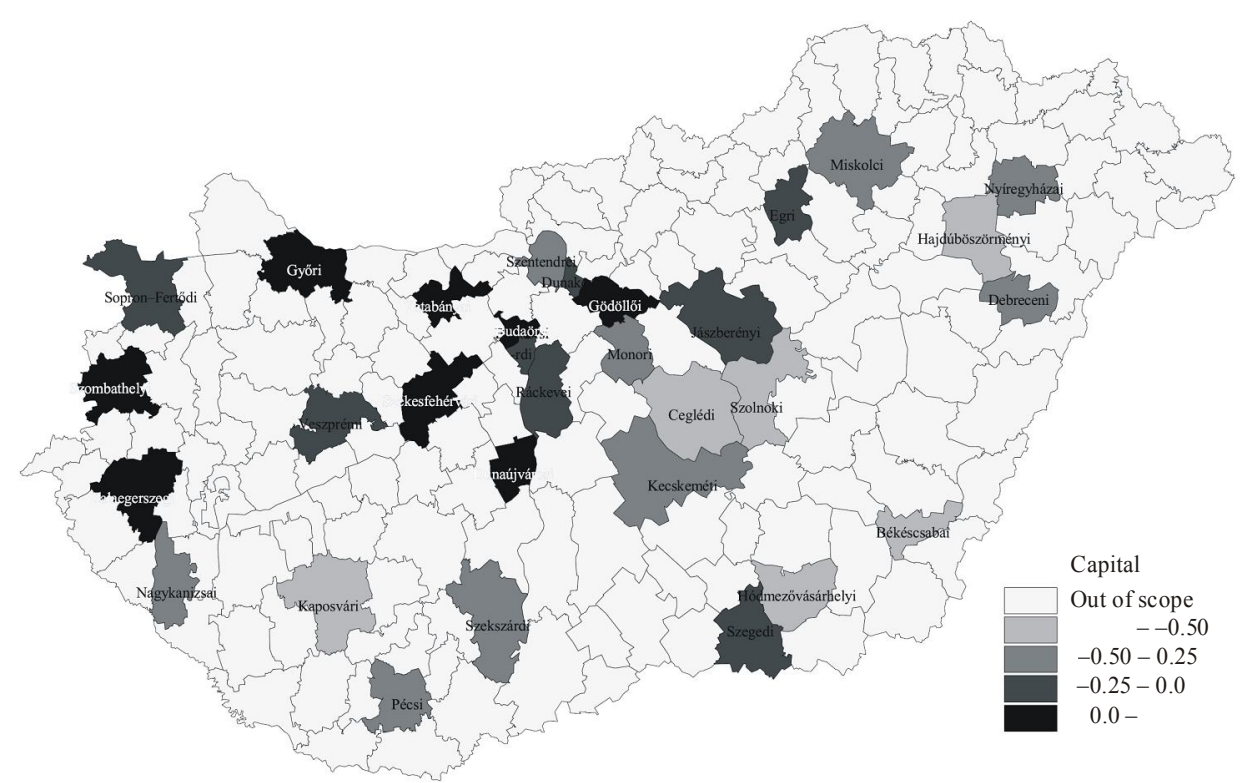

Micro-regions may be classified based on productive capital and FDI and even their spatial distribution may be determined (Figure 5): 
- most competitive 8 micro-regions, similarly to revealed competitiveness, are found in manufacturing centres of Western Transdanubia and in smaller centres around Budapest,

- the next category ( 8 micro-regions) is also dominated by regions around Budapest, but a few major cities also appear from other regions of the country,

- the third group ( 9 micro-regions) is characterized by country capitals from everywhere around the country,

- while the least competitive 6 micro-regions are found in the south and the east part of Hungary.

Classification of micro-regions based on social capital is similar to the previous ones (Figure 6). Social capital is quite strong around the capital and in western parts of the country, while it is practically missing in other regions. It has to be noted, that variables included in the factor, like unemployment rate, poverty rate, number of disability pensioners under retirement age, etc. not only describe social capital, but may also be linked to human capital.

Micro-regions by SOC_CAP factor

Figure 6

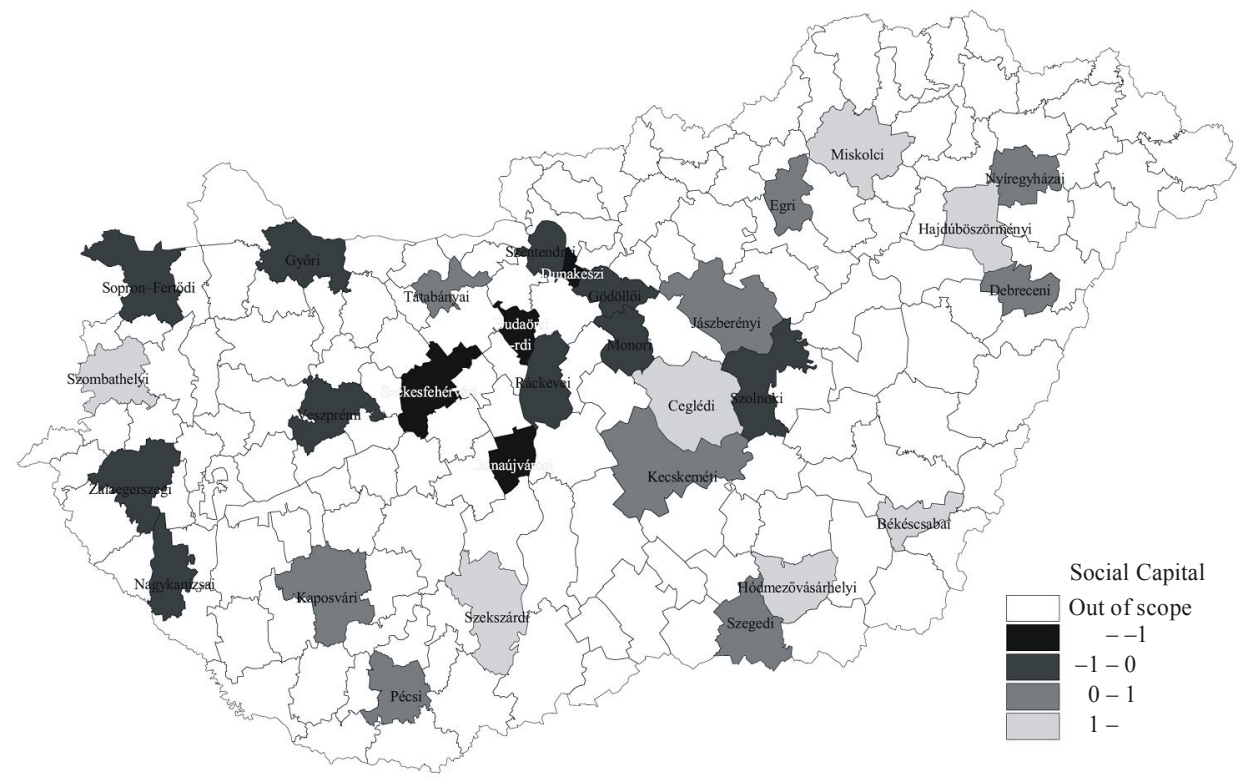

(c) Relationship between $R C$ and the factors created from the indicators

There may be multicollinearity among the indicator groups of the five competitiveness factors. Therefore we used a different methodology to review and test the relationship between the RC dependent variable and each of the 34 indicators considered: we performed factor analysis on the 34 indicators to generate independent factors. These factors were used in multivariate linear regression. This was especially beneficial because it enabled us to test the structure of the pyramidal model. However, it bears the 
disadvantage that one has to find an explanation afterwards for each factor based on the indicators included.

Factor analysis was performed for 34 variables with 4-5-6-7-8 factors; obviously, the higher the number of factors better explains the standard deviation (Table 2). We performed multivariate linear regression in each case, and found the best alignment for 5 factors:

- there is no multicollinearity to observe,

- residuals show a normal distribution,

- there is no heteroscedasticity to observe.

Table 2

Factor weights for 34-indicator factor analysis

\begin{tabular}{|c|c|c|c|c|c|}
\hline Factors & 4 factors & 5 factors & 6 factors & 7 factors & 8 factors \\
\hline 1 & 23.58 & 22.26 & 22.15 & 22.31 & 22.34 \\
\hline 2 & 21.53 & 20.76 & 20.46 & 20.19 & 20.30 \\
\hline 3 & 16.13 & 16.47 & 14.61 & 14.91 & 14.82 \\
\hline 4 & 9.85 & 9.58 & 8.95 & 8.89 & 8.66 \\
\hline 5 & - & 8.15 & 8.75 & 8.78 & 6.56 \\
\hline 6 & - & - & 6.42 & 4.98 & 5.52 \\
\hline 7 & - & - & - & 4.45 & 4.89 \\
\hline 8 & - & - & - & - & 4.38 \\
\hline Total & 71.09 & 77.22 & 81.34 & 84.51 & 87.47 \\
\hline
\end{tabular}

These five factors account for $81.1 \%\left(\mathrm{R}^{2}=0.811\right)$ of the dependent variable's $(\mathrm{RC})$ standard deviation. Our calculations resulted in the following multivariate linear regression model:

$$
R C_{i}=+0,213 F 1_{i}+0,665 F 2_{i}+0,421 F 3_{i}+0,301 F 4_{i}+0,236 F 5_{i}+e_{i} .
$$

The interpretation is complicated by the fact that each indicator may be present in more than one factor; therefore, it is recommended to consider components with an absolute value greater than 0.5 (Table 3 ).

Table 3

Factor components

\begin{tabular}{l|l|l|l|l|l|l|l|l|l}
\hline \multicolumn{2}{c|}{ Factor1 } & \multicolumn{2}{c|}{ Factor2 } & \multicolumn{2}{c|}{ Factor3 } & \multicolumn{2}{c}{ Factor4 } & \multicolumn{2}{c}{ Factor5 } \\
\hline DIPL_EMPL & 0.887 & FDI_EMPL & 0.940 & MIGR & 0.885 & EXP_GVA & 0.794 & CULT & 0.692 \\
SERVICES & 0.876 & FDI_REV & 0.939 & BIRTH_MORT & 0.795 & CLUST_PROP & 0.787 & SEC_EMPL & 0.677 \\
SELF_EMPL & 0.863 & FDI_INH & 0.933 & VITALITY & 0.694 & PAYER_PIT & 0.656 & \\
MANAG_EMPL & 0.850 & FDI_CAP & 0.931 & PATENT_OUT & 0.595 & EXP_INH & 0.636 & \\
DIPL-LOCAL & 0.817 & SHARE-INH & 0.918 & SME_INH & 0.660 & & & \\
KIMS & 0.791 & CONS-INH & 0.725 & KIBS & 0.569 & & & \\
NONGOV & 0.716 & EXP_INH & 0.626 & YOUNG_INH & 0.527 & & & \\
R\&D_INH & 0.594 & KIBS & 0.559 & POOR & -0.518 & & & \\
CRIME & 0.515 & SME_INH & 0.505 & ENTRE & -0.520 & & & \\
SCHOOL & -0.752 & & & DIS_PENS & -0.650 & & & & \\
& & & & UNEMPL_RATE & -0.688 & &
\end{tabular}


Indicators of the pyramidal model's competitiveness factors appear in several calculated factors as components (Table 4). The pyramidal model's research and technological development competitiveness factor (RTD) is only linked to one factor; we attribute this to the fact that among the studied 31 micro-regions, there is research and development only in a few university towns. Indicators of human and social capital appear in several factors, especially because these are difficult to operationalize.

Table 4

Relationship between the competitiveness factors and the calculated factors

\begin{tabular}{|c|c|c|c|c|c|}
\hline Competitiveness factors & Factor 1 & Factor2 & Factor3 & Factor4 & Factor5 \\
\hline Research and technological development & $\mathrm{x}$ & & & & \\
\hline Human capital & $\mathrm{x}$ & & $\mathrm{x}$ & & $\mathrm{x}$ \\
\hline Productive capital and FDI & & $\mathrm{x}$ & & & \\
\hline Regional specialization and clusters & & $\mathrm{x}$ & & $\mathrm{x}$ & \\
\hline Social capital and institutions & $\mathrm{x}$ & & $\mathrm{x}$ & & $\mathrm{x}$ \\
\hline
\end{tabular}

Revealed competitiveness is most broadly influenced by the Factor2, dominated by productive capital and FDI, as well as regional specialization (entrepreneurship). This factor expresses one of the elements to the pyramidal model (Productive capital and FDI), complemented by a few indicators of other elements. Spatial distribution of microregions based on this factor shows exact conformity with Figure 5.

Factor1 contains research and technological development, human capital and social capital indicators (Figure 7). Micro-regions that are strong on this factor are distributed quite evenly around the country; usually in university towns, sometimes even being the centres of less developed regions. Compared to previous results it is salient that highly competitive micro-regions of Transdanubia show weak competitiveness on human capital and RTD values.

Factor4 is linked to the pyramidal model's regional specialization and clusters element. This indicates the spatial distribution of Hungarian manufacturing industries (Figure 8). It is interesting to see that manufacturing industries with export capabilities are located in Northern Transdanubia and beyond the daily commute zone of Budapest's agglomeration.

The RCF was tested for 31 Hungarian micro-regions based on the pyramidal model. In our opinion, both analyses rendered useful results for regional policy-makers and for fine-tuning the model itself. 
Factor1: research and technological development, human capital, and

Figure 7 social capital and institutions

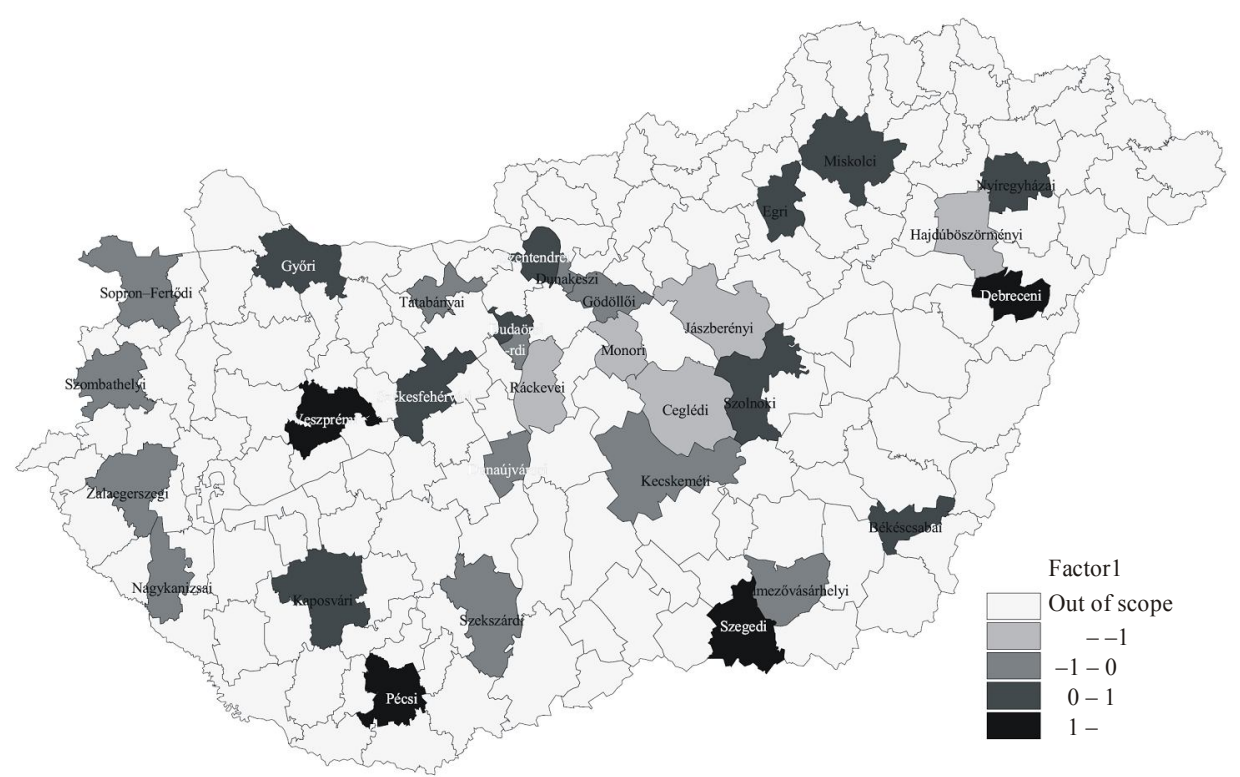

Figure 8

Factor4: regional specialization and clusters

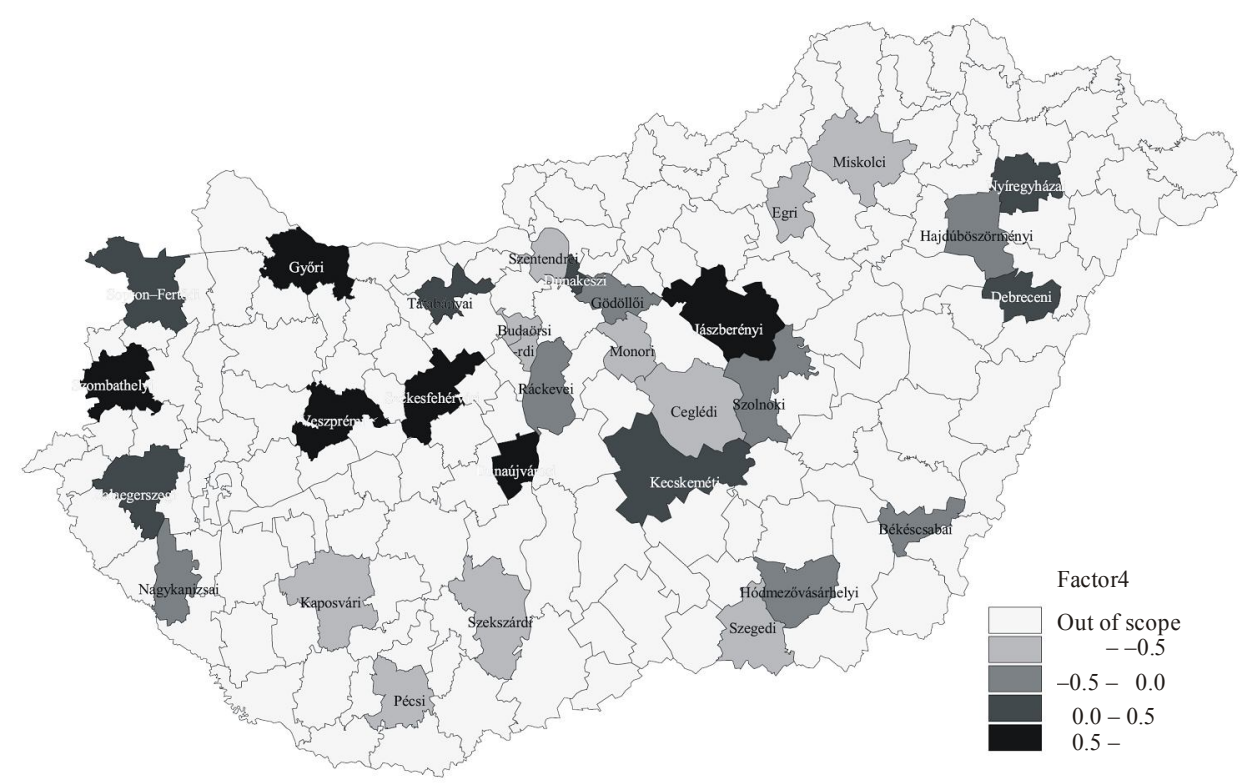




\section{Summary}

The aim of this study was to apply the pyramidal model of regional competitiveness and perform a study of LAU1 micro-regions with potential localization agglomeration economies. The pyramidal model rests on endogenous growth factors, and it reflects on competitiveness advantages and disadvantages besides measuring competitiveness itself. Influencing factors of competitiveness have been modelled by the Regional Competiveness Function, created by multivariate linear regression models.

Hungary has shown slow economic growth for about a decade, and employment figures have been falling behind the EU-average. These factors together demonstrate that the Hungarian economy is lacking competitiveness. Data shows that the area around Budapest is still growing dynamically, well exceeding the EU-average, while other parts of the country are able to stagnate at best. Regional differences in the country are enormous, among the major ones in the EU. Our research was based on the question as to why these provincial regions are unable to gain more competitiveness.

The aim of our empirical study was to analyse those provincial LAU1 micro-regions, which have an urban population of at least 50,000. The Regional Competitiveness Function was estimated in two ways, because in our opinion, both methods are useful and are able to amend each other in regional competitiveness studies. In the future, however, it will be more beneficial to examine nodal regions, which are a much better representation of business and institutional relationships.

Our empirical results show a good representation of Hungarian region types in their specific developmental phases:

- Budapest and micro-regions around it: this region, housing about 3 million inhabitants, is developing quickly, offering wide-ranging urbanization advantages.

- Manufacturing micro-regions: significant FDI and export, high employment, weak RTD and human capital. These regions are located at the north-western border and are well integrated into the EU economy, however, their labour productivity is low and foreign-owned companies do not have a wide supply base in the region. These are remote controlled regions unable to vitalize their own economies, because their human capital and innovation capacity required for higher value-added products and services and innovation is quite weak.

- University towns: excellent human capital and state-financed RTD, but a low level of export capabilities in the business sector, low levels of productive capital, labour productivity, and employment. These micro-regions are distributed around the country. They are unable to vitalize the economy of their broader region because there are no significant enterprises in the region.

- Stagnated urban micro-regions: weak human capital, low levels of export capability, usually encircled by rural settlements.

The weak performance in the Hungarian economy is partially an outcome of inadequate regional policy. There is an enormous need for decentralized territorial development in order to strengthen the competitiveness of provincial urban regions, which should also enable them to execute bottom-up development strategies more strongly adhering to the unique characteristics of each micro-region. 
There is still a long way to go towards the establishment of a Regional Competitiveness Function. The road is full of conceptual and methodological barriers. However, there is an explicit need for a better understanding of regional development in less prospective European countries. We believe that the synthesis of endogenous growth theories and regional competitiveness studies would benefit a more refined framework for empirical analyses to do this. The potential outcome is a better policy framework.

\section{REFERENCES}

Acs Zoltán - Szerb László (2007): Entrepreneurship, Economic Growth and Public Policy. Small Business Economics 28 (2-3): 109-122.

Barkley, D. L. (2008): Evaluations of Regional Competitiveness: Making a case for case studies. The Review of Regional Studies 38 (2): 212-143.

Batey, P. - Friedrich, P. (2000): Aspects of Regional Competition. In Batey, P.- Friedrich, P. (eds): Regional Competition. pp. 3-33. Springer, Berlin.

Bajmócy Zoltán - Szakálné Kanó Izabella (2009): Measuring the Innovation Performance of Hungarian Subregions. In: Bajmócy Zoltán - Lengyel Imre (eds) Regional Competitiveness, Innovation and Environment. pp. 99-121. JATEPress, Szeged.

Bajmócy Zoltán - Lukovics Miklós. - Vas Zsófia (2010): A subregional analysis of universities' contribution to economic and innovation performance. Transition Studies Review 17 (1): 134-150.

Budd, L. - Hirmis, A. K. (2004): Conceptual framework for regional competitiveness. Regional Studies 38 (9): $1015-1028$.

Camagni, R. (2002): On the Concept of Territorial Competitiveness: Sound or Misleading? Urban Studies 39 (13): 2395-2411.

Camagni, R. (2009): Territorial capital and regional development. In: Capello, R.-Nijkamp, P. (eds) Handbook of regional growth and development theories. pp. 118-132.Edward Elgar, Cheltenham.

Capello, R. (2007a): Regional economics. Routledge, London and New York.

Capello, R. (2007b): A forecasting territorial model of regional growth: the MASST model. The Annals of Regional Science 41 (4): 753-787.

Chesire, P.C. (2003): Territorial Competition: Lessons for (Innovation) Policy. In: Bröcker, J. - Dohse, D. Soltwedel, R. (eds) Innovation Clusters and Interregional Competition. pp. 331-346 Springer, Berlin.

EC (1999): Sixth Periodic Report on the Social and Economic Situation and Development of Regions in the European Union. European Commission, Luxembourg.

EC (2001): Second Report on Economic and Social Cohesion. European Commission, Brussels.

EC (2008): European Competitiveness Report 2008. European Commission, Brussels.

Faggian, A. - McCann, P. (2009): Human capital and regional development. In: Capello, R.-Nijkamp, P. (eds) Handbook of regional growth and development theories. pp. 133-151. Edward Elgar, Cheltenham.

Enyedi György (2009): Competitiveness of the Hungarian Regions. Hungarian Geographical Bulletin 58 (1): 33-48.

Fischer, M. - Nijkamp, P. (2009): Entrepreneurship and regional development. In: Capello, R.-Nijkamp, P. (eds) Handbook of regional growth and development theories. pp. 182-198. Edward Elgar, Cheltenham.

Florida, R. (2002): The Rise of the Creative Class: And How It's Transforming Work, Leisure, Community and Everyday Life. Basic Books, New York.

Gardiner, B. - Martin, R. - Tyler, P. (2004): Competitiveness, Productivity and Economic Growth across the European Regions Regional Studies Special Issue 38 (9): 1045-1067.

Glaeser, E. L. (2008): Cities, Agglomeration, and Spatial Equilibrium. Oxford University Press.

Kitson, M. - Martin, R. - Tyler, P. (2004): Regional Competitiveness: An elusive yet key concept? Regional Studies 38 (9): 991-999.

Lengyel Balázs - Cadil, V. (2009): Innovation policy challenges in transition countries: foreign business R\&D in the Czech Republic and Hungary. Transition Studies Review 16 (1): 174-188.

Lengyel Balázs - Leydesdorff, L. (2010): Regional innovation systems in Hungary: The failing synergy at the national level. Regional Studies 45 (5): 677-693. 
Lengyel Imre (2000): A regionális versenyképességről (On regional competitiveness). Közgazdasági Szemle 47 (12): 962-987.

Lengyel Imre (2004): The Pyramid Model: Enhancing Regional Competitiveness in Hungary. Acta Oeconomica 54 (3): 323-342.

Lengyel Imre (2009a): Knowledge-based local economic development for enhancing competitiveness in lagging areas of Europe: The case of the University of Szeged. In: Varga Attila (ed.) Universities, Knowledge Transfer and Regional Development: Geography, Entrepreneurship and Policy. pp. 322-349. Edward Elgar, Cheltenham-Northampton.

Lengyel Imre (2009b): Bottom-up Regional Economic Development: Competition, Competitiveness and Clusters. In: Bajmócy Zoltán - Lengyel Imre (eds) Regional Competitiveness, Innovation and Environment., pp. 13-38 JATEPress, Szeged.

Lukovics Miklós (2009): Measuring Regional Disparities on Competitiveness Basis. In: Lengyel Imre Bajmócy Zoltán (eds) Regional Competitiveness, Innovation and Environment. pp. 39-53. JATEPress, Szeged.

Malecki, E. J. (2002): Hard and Soft Networks for Urban Competitiveness. Urban Studies 39 (5-6): 929-945.

Malecki, E. J. (2004): Joyckeing for position: What it Means and Why It Matters to Regional Development Policy When Places Compete. Regional Studies 38 (9): 1101-1120.

McCann, P. (2008): Agglomeration economics. In: Karlsson, C. (ed) Handbook of Research on Cluster Theory. pp. 23-38. Edward Elgar, Cheltenham.

Pike, A. - Rodrígues-Pose, A. - Tomaney, J. (2006): Local and regional development. Routledge, New York.

Polenske, K. R. (2004): Competition, Collaboration and Cooperation: An Uneasy Triangle in Networks of Firms and Regions. Regional Studies 38 (9): 1029-1043.

Porter, M. E. (2003): The Economic Performance of Regions. Regional Studies 37 (6-7): 549-578.

Porter, M. E (2007): Competitiveness: implications for Central Europe and the Czech Republic. Paper presented in Prague, 22 October.

Porter, M. E (2008): Regional Competitiveness in a Global Economy. The Summit for American Prosperity, The Brookings Institution, Washington, 11 June.

Porter, M. E.-Delgado, M.-Ketels, C.-Stern, C. (2008): Moving to a New Global Competitiveness Index. In: The Global Competitiveness Report. pp. 45-63. World Economic Forum, Davos.

Stimson, R. - Robson, A. - Shyy, T-K. (2009): Modeling regional endogenous growth: an application to the non-metropolitan regions of Australia. The Annals of Regional Science (43 (2): 379-398.

Stimson, R. - Stough, R. R. - Salazar, W. (2009): Leadership and Institutions in Regional Endogenous Development. Edward Elgar, Cheltenham.

Szakálné Kanó Izabella (2011): A gazdasági akitivitás térbeli eloszlásának vizsgálati lehetőségei. Statisztikai Szemle, 89 (1): 77-100.

Varga Attila (2006): The Spatial Dimension of Innovation and Growth: Empirical Research Methodology and Policy Analysis. European Planning Studies 14 (9):. 1171-1186.

Varga Attila (2007): Localized knowledge inputs and innovation: The role of spatially mediated knowledge spillovers in Hungary. Acta Oeconomica 57 (1): 1-20.

Keywords: regional competitiveness, pyramidal model, endogenous regional development, regional competitiveness function.

Abstract

Nowadays, more and more scholars of regional science are interested in the role of agglomeration economies in the knowledge-based economy. This issue can be dealt with from different points of view: different development types of functional or nodal regions with the examination of the factors influencing regional competitiveness

In this paper, we outline our analytical framework: the renewed pyramidal model of regional competitiveness. The renewed pyramidal model is a logical systematization for measuring endogenous regional development and the factors influencing it; the model shall be used to introduce the regional competitiveness function (RCF). After introducing theoretical model and new function, we are going to investigate the competitiveness of Hungarian urban microregions (LAU1), where firms potentially enjoy localization agglomeration economies. The statistical analysis to underline the classification of microregions by competitiveness types is based on multivariate linear regression models. 